\title{
TWO NOVELTIES IN GENUS PLATYSTELE (ORCHIDACEAE: PLEUROTHALLIDINAE) FROM COSTA RICA
}

\author{
AdAM P. KarRemans ${ }^{1,2} \&$ Diego Bogarín ${ }^{1,2,3}$ \\ ${ }^{1}$ Lankester Botanical Garden, University of Costa Rica. P.O. Box 302-7050 Cartago, Costa Rica. \\ ${ }^{2}$ Naturalis Biodiversity Center, The Netherlands. \\ ${ }^{3}$ Herbario UCH, Universidad Autónoma de Chiriquí, 0427, David, Chiriquí, Panama. \\ *Author for correspondence: adam.karremans@ucr.ac.cr

\begin{abstract}
Two new species of Platystele allied to the P. oxyglossa complex are described from Costa Rica. Platystele carl-lueriana can be distinguished from $P$. catiensis and $P$. oxyglossa by the compact inflorescence that barely exceeds the leaf, from $P$. pedicellaris by the large plants with long leaves and small flowers, and from P. tausensis by the yellowish sepals and petals ( $v s$. purple stained) and the minutely glandular ( $v s$. apically hirsute) lip. The second species, Platystele jane-lueriana, can be easily distinguished by the glabrous flowers, and the conspicuously inflated, bulbous lip, with an incurved apex. Among the other members of the complex, it is most closely resembles $P$. pedicellaris in the compact inflorescence that is subequal to the leaves, but is distinguished by tail-less sepals and the linear-ligulate petals. With these additions, the total number of Costa Rican Platystele reaches twenty species.
\end{abstract}

KeY wORDs: Flora of Costa Rica, new species, Platystele carl-lueriana, Platystele jane-lueriana, taxonomy

Introduction. Platystele Schltr. belongs to subtribe Pleurothallidinae and currently includes about 110 species (Karremans et al. 2016). The genus is closely related to Scaphosepalum Pfitzer and Teagueia (Luer) Luer, all belonging to the Specklinia Lindl. affinity (Pridgeon, Solano \& Chase 2001, Karremans 2016). Species of Platystele can be recognized by the small plants, the tiny flowers, which are frequently flat, with free and spreading sepals and petals, a simple lip with a basal glenion, a short column with an apical anther and bilobed stigma (Luer, 1990).

In the latest monographic study of the genus from Costa Rica, Luer (2003) recorded 13 species. Subsequent authors added five species Platystele catiensis Karremans \& Bogarín, P. speckmaieri Luer \& Sijm, P. sylvestrei Karremans \& Bogarín, P. tausensis Bogarín \& Karremans, and P. tica Karremans \& Bogarín to the country's flora (Bogarín \& Karremans 2010, Fernández, Bogarín, Karremans \& Jiménez 2014, Rakosy, Speckmaier, Weber, Huber \& Weissenhofer 2013).

While revising material of Platystele in preparation for a revision of the genus from Costa Rica, we encountered two unnamed entities. Unfortunately, we were unable to retrieve any additional material for study, and have to rely on what is currently available to name these two distinct taxa. They are described here forth bringing the total number of species of Costa Rican Platystele to twenty.

\section{TAXONOMIC TREATMENT}

Platystele carl-lueriana Karremans \& Bogarín, sp. nov. (Fig. 1-2).

TYPE: Costa Rica. Limón: Pococí, Guápiles, Jiménez, $10^{\circ} 10^{\prime} 09.35^{\prime} \mathrm{N} 83^{\circ} 46^{\prime} 54.94^{\prime \prime} \mathrm{W}, 457 \mathrm{~m}$. En árboles solitarios en potreros. Floreció en cultivo en la colección personal de Gerson Villalobos el 29 de agosto 2014, A.P. Karremans 6310 (holotype, JBL-Spirit).

Platystele carl-lueriana is florally similar to $P$. catiensis and P. oxyglossa Schltr., but can be easily distinguished the compact inflorescence that barely exceeds the leaf (versus an elongate, loosely flowered inflorescence).

Plant minuscule, epiphytic, caespitose, erect, up to $2.4 \mathrm{~cm}$ tall, including the inflorescence. Roots basal, flexuous, filiform. Ramicauls erect, slender, abbreviated, enclosed by tubular, imbricating, slightly compressed, membranous sheaths, becoming brownish 


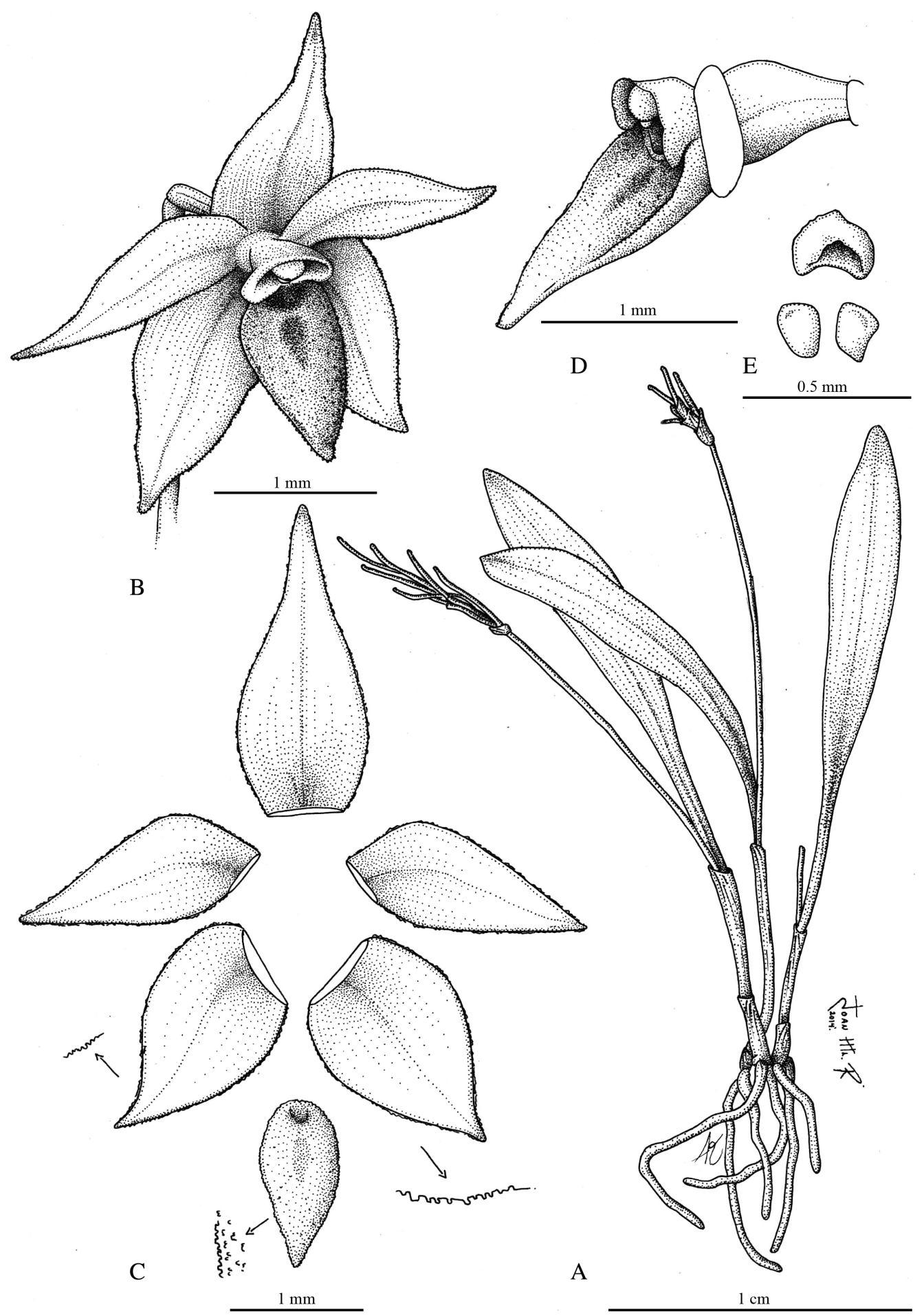

FiguRE 1. Platystele carl-lueriana Karremans \& Bogarín. A. Habit. B. Flower. C. Dissected perianth. D. Ovary, column and lip, lateral view. E. Anther cap and pollinarium. Drawing by A.P. Karremans and Joan Ramírez from the holotype. 


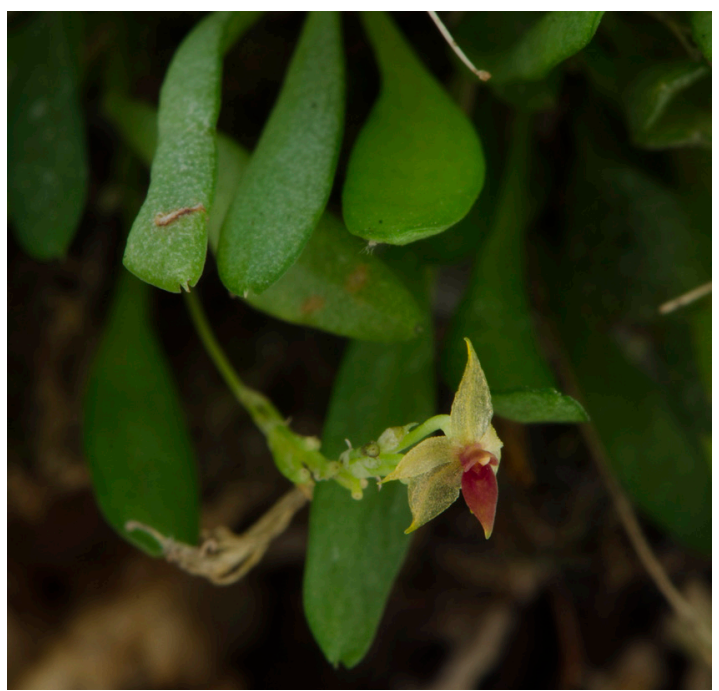

Figure 2. Platystele carl-lueriana Karremans \& Bogarín showing the relatively elongate leaves and congested inflorescence. Based on the plant that served as type. Photograph by A. P. Karremans.

and papery with age. Leaf narrowly-elliptic to ligulate, erect, conduplicate, subacute, emarginate, abaxially keeled and terminating in a short apiculus, 1.9-2.1 $\times$ $0.1-0.2 \mathrm{~cm}$, narrowed at the base into a conspicuous, conduplicate petiole. Inflorescence racemose,distichous, congested, successively flowered, with one flower open at a time, shortly surpassing the leaf, up to $2.2 \mathrm{~cm}$ long, peduncle to $1.8 \mathrm{~mm}$ long, pedicels 2-3 mm long. Floral bracts acute, conduplicate, to $0.1 \mathrm{~mm}$ long. Ovary terete, smooth, to $0.6 \mathrm{~mm}$ long. Flower with the sepals and petals yellowish, the lip and column red. Dorsal sepal narrowly ovate to lanceolate, acute-acuminate, margin erose-dentate, spreading, 2.3 $\times 1.0 \mathrm{~mm}$. Lateral sepals subequal to the dorsal sepal, slightly oblique, ovate, acute, shortly apiculate, margin erose-dentate, spreading, $1.7-1.8 \times 1.0-1.1 \mathrm{~mm}$. Petals obliquely lanceolate to narrowly-ovate, margin erosedentate, spreading, acute, 1-veined, 1.8-1.9 × 0.7-0.8 $\mathrm{mm}$. Lip narrowly-ovate, acute, margin erose-dentate, glandular, with a small glenion at the base, $1.2-1.3 \mathrm{~mm}$ $\times 0.6 \mathrm{~mm}$. Column short, sub-cylindrical, $0.3-0.4 \mathrm{~mm}$ long. Anther apical cucullate, pollinia two, laterally flattened. Stigma subapical, transversely bilobed at each side of the anther.

Eponymy: The name honors Carlyle A. Luer on his 95th birthday. Luer has dedicated four decades to the

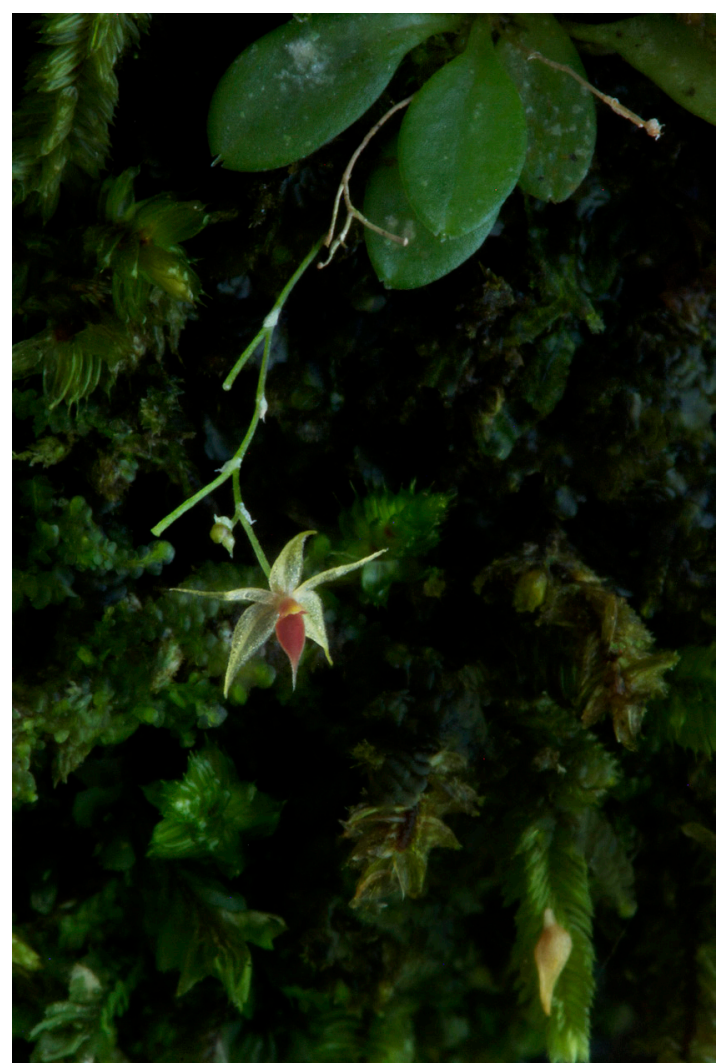

FIgURE 3. Platystele catiensis, (Karremans 5442, JBLspirit). Photograph by A.P. Karremans.

study of Pleurothallidinae, his work set a solid base for other authors to study the species of this tremendously diverse and complex subtribe. It is in great part thanks to his monographs that we are now able to reveal the novelties here described.

Phenology: Plants were registered to flower in August.

Habitat and distribution: Apparently endemic to Costa Rica, where it is known only from the type locality. Plants grow in secondary forest, at about 457 $m$ in elevation.

The new species is a member of the Platystele oxyglossa species complex. It can be easily distinguished from the florally similar P. catiensis (Fig. 3) and P. oxyglossa Schltr. (Fig. 4) by the compact inflorescence that barely exceeds the leaf (versus an elongate, loosely flowered inflorescence). The most vegetatively similar species are $P$. pedicellaris (Schltr.) Garay (Fig. 5) and P. tausensis (Fig. 6), the first is 


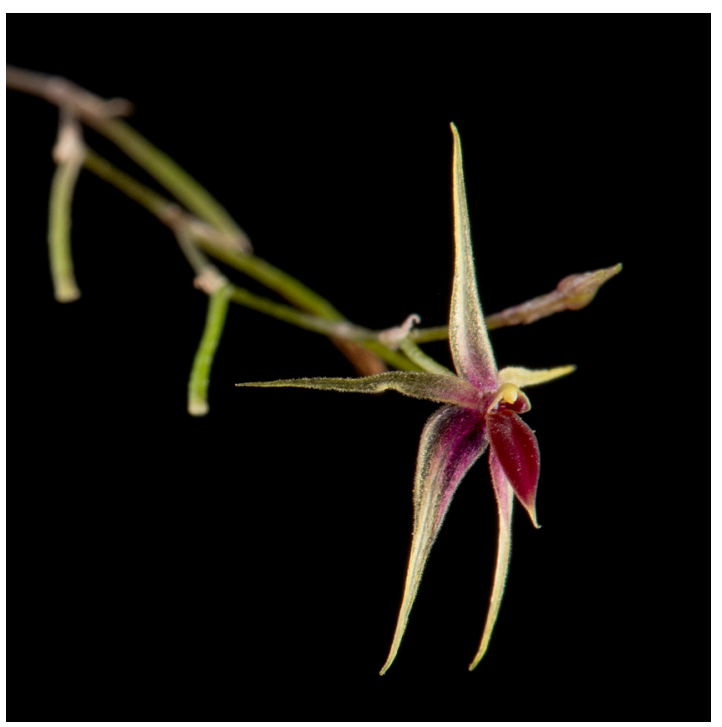

Figure 4. Platystele oxyglossa (Karremans 7074, JBLspirit). Photograph by A.P. Karremans.

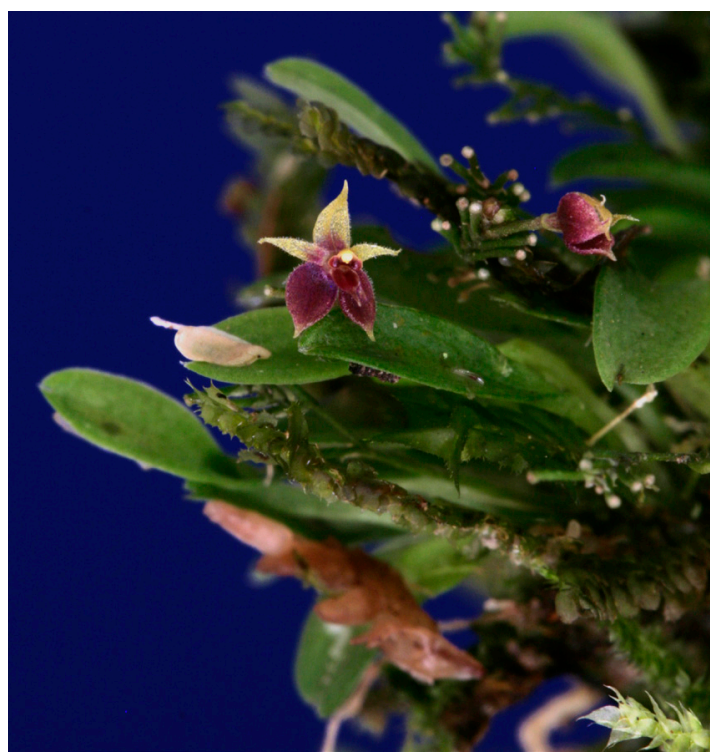

Figure 6. Platystele tausensis (Bogarín 7394, JBL-spirit). Photographed by D. Bogarín.

easily distinguished by the shorter plants and larger flowers (sepals $1.7-2.0 \times 1.0-1.1 \mathrm{~mm}$ vs up to $6 \times$ $2.0 \mathrm{~mm}$ ), and the second by the purple stained sepals and petals (vs. yellow-green) and the hirsute lip apex (vs. glabrous). The new species is also somewhat reminiscent of P. propinqua (Ames) Garay (Fig. 7), but differs in the narrow, acuminate lateral sepals, petals and lip (vs. lateral sepals and lip ovate and acute).

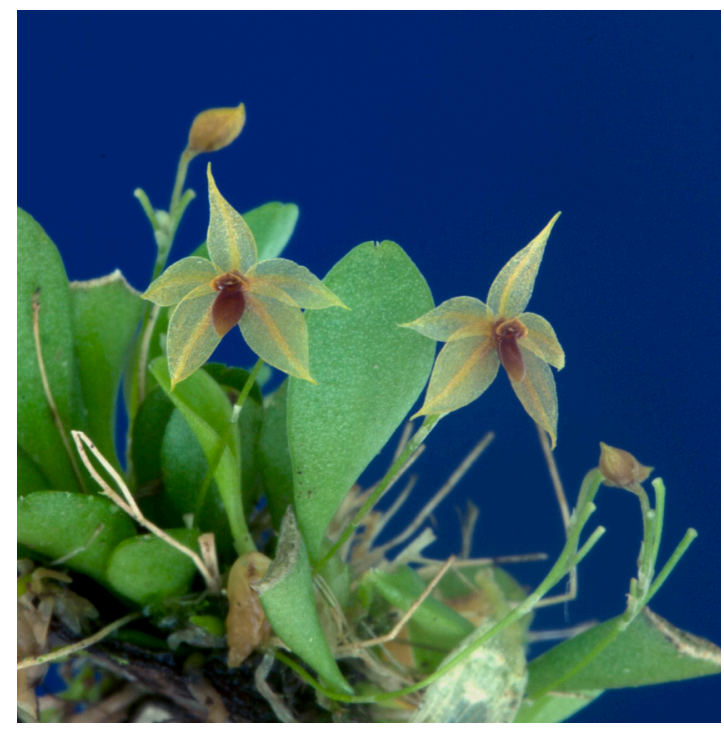

Figure 5. Platystele pedicellaris (Karremans 2628, JBLspirit). Photograph by D. Bogarín.

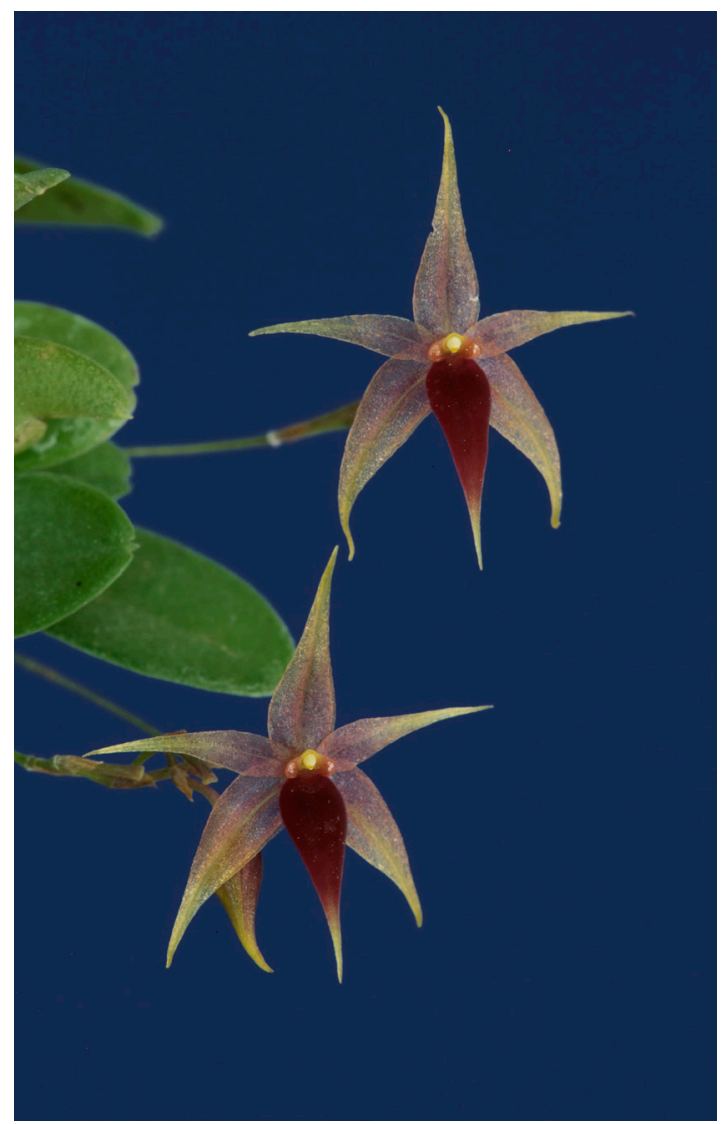

FIgURE 7. Platystele propinqua (Karremans 917, JBLspirit). Photograph by D. Bogarín. 
Platystele jane-lueriana Karremans \& Bogarín, sp. nov. (Fig. 8).

TYPE: Costa Rica. Cartago: Turrialba, Moravia de Chirripó, hills north of Moravia across the plain

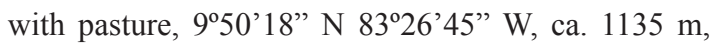
premontane wet forest, secondary mature vegetation and remnants of secondary vegetation in pastures, 12 June 2002, F. Pupulin 3971, M. Bonilla, R. Gómez, H. Léon-Páez \& W. Schug (holotype, JBL-Spirit!).

Similar to Platystele pedicellaris, but is distinguished by tail-less sepals and the linear-ligulate petals (vs. acuminate sepals and elliptic petals).

Plant minuscule, epiphytic, caespitose, erect, up to $1.3 \mathrm{~cm}$ tall, including the inflorescence. Roots basal, flexuous, filiform. Ramicauls erect, slender, abbreviated, enclosed by tubular, imbricating, slightly compressed, membranous sheaths. Leaves elliptic, erect, thick, conduplicate, subacute, emarginate, abaxially keeled and terminating in a short apiculus, $6.5-9.0 \times 2.1-2.7 \mathrm{~mm}$, narrowed at the base into a conduplicate petiole. Inflorescence racemose, distichous, successively flowered, with one flower open at a time, up to $1 \mathrm{~cm}$ long, peduncle to $8.5 \mathrm{~mm}$ long, pedicels $1 \mathrm{~mm}$ long. Floral bracts acute, conduplicate, to 3-5 mm long. Ovary terete, smooth, to $5 \mathrm{~mm}$ long. Dorsal sepal narrowly lanceolate-elliptic, acute, with a conspicuous mid-vein, spreading widely, $4.8 \times$ $1.4 \mathrm{~mm}$. Lateral sepals subequal to the dorsal sepal, narrowly ovate, with a conspicuous mid-vein, acute, with a conspicuous mid-vein, spreading widely, 4.3$4.5 \times 1.8-2.0 \mathrm{~mm}$. Petals spreading widely, narrowly linear-ligulate, acute, 1-veined, 4.5-4.8 $\times 0.8-1.1$ $\mathrm{mm}$. Lip ovate-elliptic, shortly acuminate, apically incurved (in the only specimen), glabrous, with a small glenion at the base, $4.0 \times 1.7 \mathrm{~mm}$. Column short, subcylindrical, $0.6 \mathrm{~mm}$ long. Anther apical, Pollinia not seen. Stigma subapical, transversely bilobed at each side of the anther.

EPONYMy: The name honors Jane Luer, wife and long life companion of Carl Luer, and who undoubtedly has played a key role in these four decades of Luer's studies of the Pleurothallidinae.

Phenology: The plant was registered to flower in June, however, likely its flowering period is much longer.
Habitat and distribution: Apparently endemic to Costa Rica, where it is known only from the type locality around Moravia de Chirripó in the Caribbean watershed of Cordillera de Talamanca. Plants grow in secondary forest at $1135 \mathrm{~m}$ in elevation.

Among the species of the P. oxyglossa complex, $P$. jane-lueriana can be distinguished by the glabrous flowers, and the conspicuously inflated, bulbous lip, with an incurved apex (at least in the studied specimen). It most closely resembles Platystele pedicellaris in the compact inflorescence that is subequal to the leaves, but is distinguished by tail-less sepals and the linearligulate petals (vs. acuminate sepals and elliptic petals).

ACKNOWLEDGMENTs. This manuscript was prepared as part of a dedicatory issue commemorating the 95th birthday of Carl Luer, who's extensive work on the Pleurothallidinae is the basis for most current studies in the subtribe, including the present. We owe thanks to Gerson Villalobos for aiding this study with providing plant material and localities. Joan Ramírez is thanked for the two illustrations of the new species. We thank two anonymous reviewers for their kind comments that improved the manuscript. We are also thankful to the Costa Rican Ministry of Environment and Energy (MINAE) and its National System of Conservation Areas (SINAC) for the scientific permits. We thank the Vice-Presidency of Research of the University of Costa Rica for providing support through the project: "Taxonomía, filogenia molecular, aislamiento reproductivo y diferenciación de nichos de Specklinia endotrachys" (814-B3075).

\section{LiTERATURE CITED}

Bogarín, D. \& Karremans, A. P. (2010). A new Platystele (Orchidaceae: Pleurothallidinae) from Central Costa Rica / Un nuevo Platystele (Orchidaceae: Pleurothallidinae) de la parte central de Costa Rica. Orquideología, XXVII(2), 208-220.

Fernández, M., Bogarín, D., Karremans, A. P. \& Jiménez, D. (2014). New species and records of Orchidaceae from Costa Rica III. Lankesteriana, 13(3), 259-282.

Karremans, A. P. (2016). Genera Pleurothallidinarum: an updated phylogenetic overview of Pleurothallidinae. Lankesteriana, 16(2), 219-241.

Karremans, A. P., Albertazzi, F. J., Bakker, F. T., Bogarín, D., Eurlings, M. C. M., Pridgeon, A., Pupulin, F. \& Gravendeel, B. (2016). Phylogenetic reassessment of Specklinia and its allied genera in the Pleurothallidinae (Orchidaceae). Phytotaxa, 272(1), 1-36. 


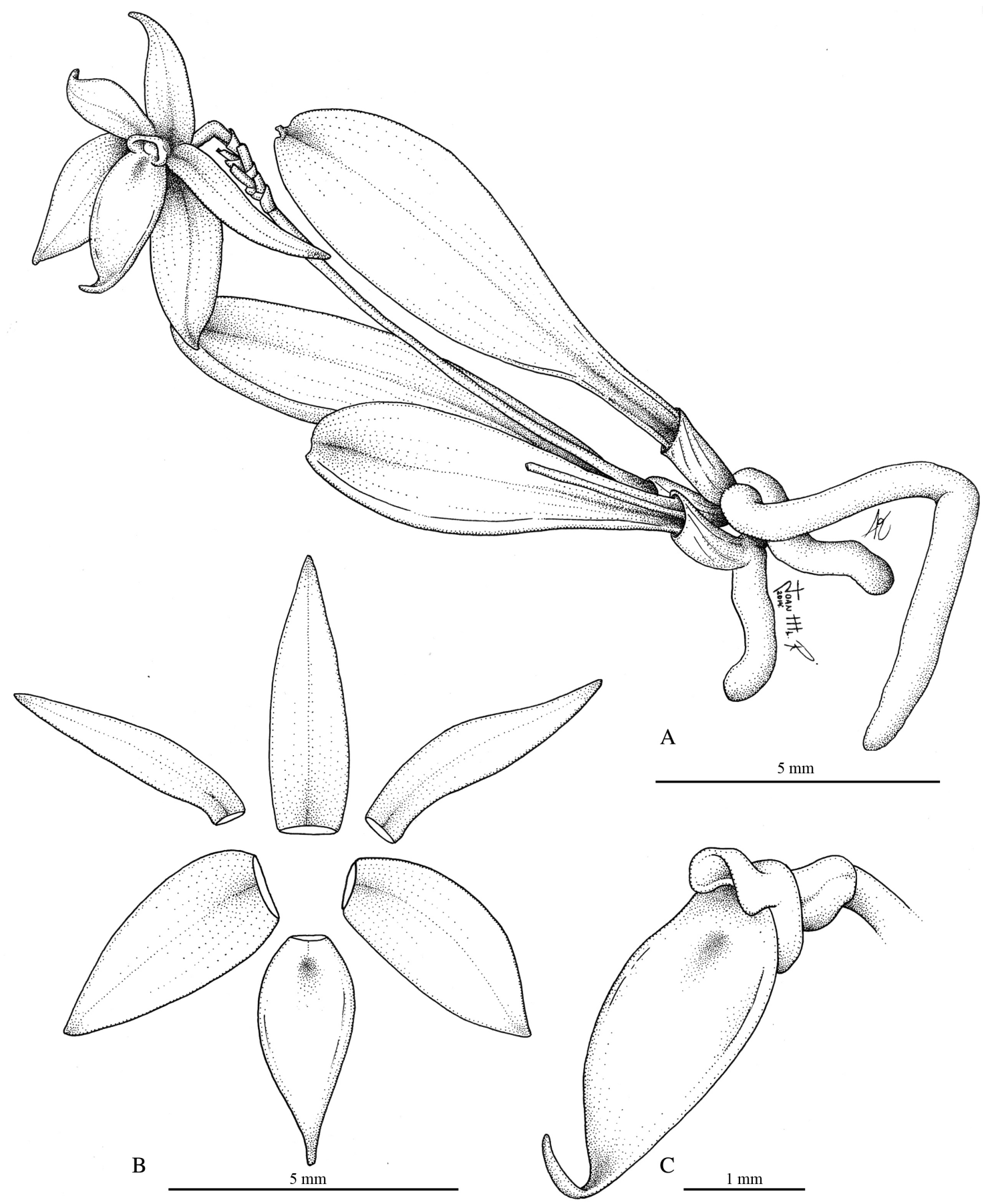

FIGURE 8. Platystele jane-lueriana Karremans \& Bogarín. A. Habit and flower. B. Dissected perianth. C. Ovary, column and lip, lateral view. Drawing by A.P. Karremans and Joan Ramírez from the holotype. 
Luer, C. A. (1990). Pleurothallidinarum VII. Systematics of Platystele. Monographs in Systematic Botany from the Missouri Botanical Garden, 38, 1-135.

Luer, C. A. (2003). Platystele. In: B. E. Hammel, M. H. Grayum, C. Herrera \& N. Zamora (Eds.), Manual de Plantas de Costa Rica. Vol. 3. Monocotiledóneas (Orchidaceae-Zingiberaceae). Monographs in Systematic Botany from the Missouri Botanical Garden, 93, 381-386.
Pridgeon, A. M., Solano, R. \& Chase, M. W. (2001). Phylogenetic relationships in Pleurothallidinae (Orchidaceae): combined evidence from nuclear and plastid DNA sequences. American Journal of Botany, 88, 2286-2308.

Rakosy, D., Speckmaier, M., Weber, A., Huber, W., Weissenhofer, A. (eds) (2013). Orchids: Botanical Jewels of the Golfo Dulce Region, Costa Rica. Vienna, Austria: Verein zur Förderung der Tropenstation La Gamba. 
